\title{
Women And Media: An Ethical Analysis
}

\author{
Abida Perveen \\ Sheikh Zayed Islamic Center \\ University of Karachi \\ Muhammad Shazad \\ Department of Media Studies \\ Islamia University, Bahawalpur
}

\begin{abstract}
Media is the collective communication outlets or tools that are used to store and deliver information or data. Media means technology that is intended to reach a mass audience. Ethics is the branch of knowledge that tests with moral principles. Ethics is a system of the ethics is concerned with what is good for individuals and society and is also described as moral philosophy. Media ethics are a complex topic because they deal with an institution that must do things that generally people in ordinary circumstances would not do, those communication ethics focuses on moral characters, social values related to the women protection the significant segment of the society. Women play on important role in reforming the society. The media has a critical role to play in shaping people's opinion and perceptions through the way it reports the news of women issues. There are some important ethical considerations which the media should take into account before reporting on women's problems. The media also needs to focus on different aspects of the society at large to gradually bring awareness regarding the status of women and change orthodox mindsets which are based against women. This article discusses ethical consideration of media regarding women issues.
\end{abstract}

Keywords: Women, Media, Ethical Analysis.

$$
\begin{aligned}
& \text { تلخيص }
\end{aligned}
$$

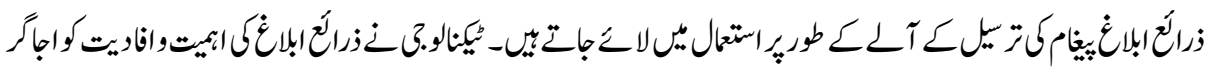

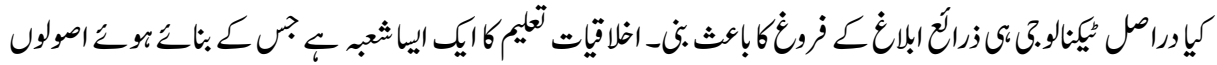

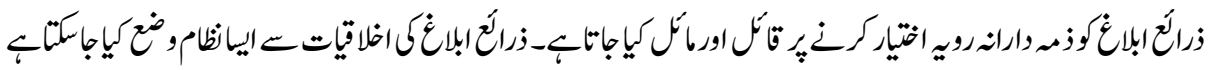

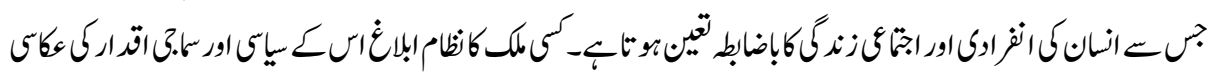

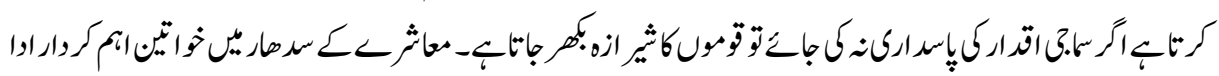

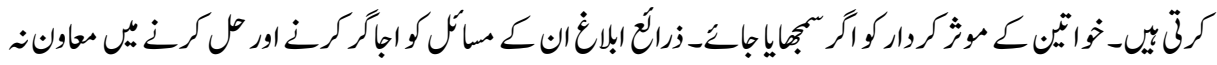

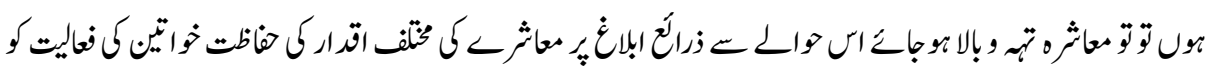

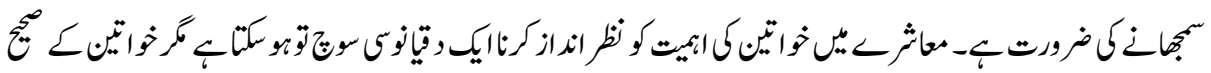




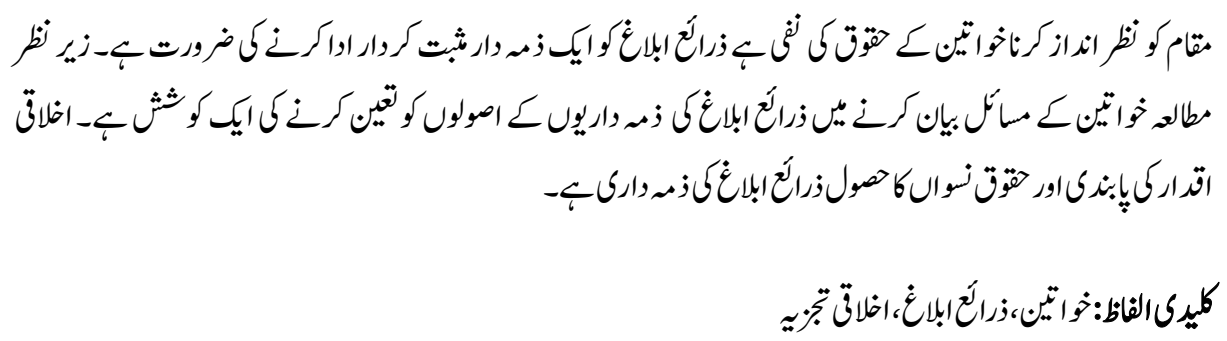

\section{Introduction}

The word ethics comes from the Greek word "ethos" meaning "customs" or "practice'. It is that branch of Philosophy whose purpose is to describe "moral sentiments" and to establish norms for " good and fair" dealing (Bromley, 1994). The ethical consideration are linked with human rights. Human Rights are rights and freedom to which all humans are entitled. Human Rights are rights when an inherent to all human beings, whatever our nationality, place of residence, national or ethic origin, colour, religion, language, or any other status, we are all equally entitled to our human rights without gender discriminative, Why Human Rights are important? Human Rights are very important. Human Rights should be the same for all people no matter what background is their race, origin or gender. They have their rights which are the same as our and they should be respected. Prophet Muhammad (Peace be Upon Him) fourteen Hundred years back before gave a complete package of human rights in the farewell sermon. He (peace be upon him) protected of rights of women and ensured "people", your women have got rights over you' (Sani, 1999). Islam provides the basis and guidelines for the protection of women rights.

This article will study the ethical consideration of women rights as human rights and role of media, which are collective outlet tools used for delivery of information. The significant role that media have in determine the part being played by man and women is undeniable. Every society comprises of certain values, and media not rally stapes but reflects the values present in society. Media have a vital and critical role play in shaping the life of a society and state, as it is the media that not only influence public policy but reinforce gender, racial and other discriminations present in the society. Media plays an important role in shaping of perception around women and their role in society. Media are also a key player in transforming negative stereotypes around women and perception around gender based violence. With the wider reach of the media aware of various issues and ills in the society, specially relating to woman, comes media hold tremendous responsibility. Ironically, however, the news items associated with women have been less laudatory and more vindictive, often laying the balance on this shoulder for being the imitators of crime. 


\section{Ethical Consideration}

According to researches conducted by the United Nations and other relevant bodies and reports published in newspapers women and men are playing their roles which link men with strength, leadership, independence and decision making and women with the very opposite of these characteristics. Male journalists regards a husband's causing serious bodily harm to him wife as simply a private domestic affairs worthy of any publicity. This problem of lack of coverage of violence against women in developing societies like Pakistan was caused by more or less the same in sensitivity of male journalists who assigned reporters to various jobs or it was because of absence of women journalists is decision making positions in media. Michael Munezike is his book said:

"Poverty and violence against women were only two of many subjects that could occupy much more prominent positions in African newspapers pages as well as prime time TV and radio programmes. Other subjects ignored by other male journalists insensitive to gender issues or lack of female journalists to cover them'” (Kunczik, 1999).

This issues like unfair opportunities in jobs, education opportunities, polygamy and forced early marriages, lack of legal knowledge among women victimised by men, health issues such as illegal abortions endangering women's lives, unequal partnership in marriages and cultural and religions beliefs that tended to go against women's human rights are very alarming.

The most attractive media television dominated by feature films and film based programs that exploit the female form of tittle-tattle gossip or through their socially insensitive approach, simply trivialize and debase the image of womanhood. It is therefore urged not only a reduction of the number of future films and film based programs on television, but more positively, the corporation of the " women's dimension" in all programs and the need for a separate focus on and for women. The formulation of a clear guidelines regarding the positive portrayal of women on television, and system of monitoring the implementation of these guidelines. Journalists have a duty to maintain the highest

professional and ethical standards. It is mentioned in the code of conduct prepared by the National Union of Journalists (London).

"A journalist shall only mention a person's race, colour, greed, illegitimacy, marital status or lack of it, gender or sexual orientation if this information is strictly relevant" (Robertson, 1995). As a communicator of a message he/she should neither originate nor process material which encourage, gender discrimination. The gender discrimination creates conflict in the society, which shall be curtail by the media men. Media men subscribe to the news values called conflict. When people fight that is news. When they make peace this is not news. This has to be changed. Communication can certainly 
contribute to the peace efforts by going easy on this news value. Conflict can be avoided with careful, balanced used of words. Most codes of ethic have been adopted to avoid conflicts of interest and other threats to media integrity.

The duty of the media communicator is to serve the truth, The mass media believe in public enlightenment as the forerunner of justice both for men and women, and to seek truth as a part of public right to know the truth. The responsibility requires media person to perform both intelligence for men and women with intelligence, objectivity, accuracy and fairness.

The public right to know is the overriding mission of the mass media. Societies as a whole cannot survive if they are not properly informed about the conditions of masses (both men and women), political affairs, international and local events through communication. "Communication taken as a whole, is incomprehensive without reference to its political dimension, its problems cannot be resolved without taking into account of political relationship. Politics to use the word in the levated sense has an indissoluble relationship are those with between communication's (Shamsuddin, 2014). The crucial relationship are these between communication and power and between communication and freedom to men and women in societies. Various conceptions of what these relationships should be are upheld in different parts of the world, responding to various traditions, resources, social systems and the development need. There may be some prospects of broad general agreement, especially if more realism and less emotional, more flexibility and less bias are introduced into the argument which has too often been inward looking and intolerant towards females. There is need for orientation for policy makers, programming and production staff so that they are sensitised to social issues with particular reference to women's issues and their implications in society. The carefully scrunting of all advertisement shown on television to ensure that they do not portray women in derogatory and stereotyped ways. The need for those programs in which the audience critics commentators, women organizations are called upon to analyse and evaluate the programme related to women issues.

The Mac Bride Common Report (UNO) argues that the media has the following responsibilities (Seen, 1980).

- Contractual responsibility in relations to his/ her media and his/ her internal organization.

- A social responsibility entailing obligation towards public opinion and society as a whole.

- Responsibility or liability deriving from the obligation to comply with the law.

- Responsibility towards international community, relating to respect of human values. 
The commission felt that codes of ethics at national and in some cases at the regional level are desirable, provided that such codes are prepared and adopted by the profession itself without government's interference.

Code of ethics should be based on public interest and should take into account the following concepts (Seen, 1980).

- Freedom of access to information sources.

- Safeguarding freedom of information.

- Objectivity, accuracy, truthfulness or the non misrepresentation of facts.

- The obligation to refrain from calumny, unfounded accusations, slander, violations of privacy.

- Integrity and independence.

- The right of reply and correction.

- Respect of professional confidentiality.

- Consideration for the cultural, social or ethnic of individual countries and

- Responsibility to the public, and its right and interest and in relation to national racial and religious communities, the nation, the state and maintenance of peace.

\section{State of Media in Covering Woman Issues}

Peace cannot be attain in the societies if women are not given importance and their coverage in the media is not at per with men.

The most ambitious contact analysis of Television Programming to investigate the representation of women was conducted at the Department of Mass Communication, University of Karachi in 2014. Programmes over a period of 15 days ( a sample of 70 news programs , 30 special interest programs, 185 commercials and two audience contract programs, a total sample of 362 items were securitized for women related references. The largely quantitative analysis indicated certain definite trends:

- 30 special interest group programs,

- 33 art and entertainment programs,

- 26 fiction oriented and cinema programs, 185 commercials and three audience

- 185 commercials and three audience

- Contact program

- A total sample of 364 items were securitized for women related reference. The largely quantitative analysis indicated certain trends:

- News related to women did not exceed 2.5 minutes out of total 20minutes. Women news maker in less than ten percent of the 30 news programs telecast, mostly in the foreign news items that related women's rulers in the would politics. 
- Women invariably signed in the political news as mothers, wives, daughters of well know ken. They also appeared frequently as members of audiences and as victims of some accident or calamity.

- A significant number of women appeared as shoppers. In developmental orientednews items, women featured as workers in free plantations, poultry farming etc and as a beneficiaries of welfare so haves.

- In women's programs the for focus was the women at home. The experts of these programs were men. For example in farmers programs all the experts were man; women, however, compared most children's programs.

- So far commercials were concerned, the focus was on woman, the lifestyles promoted were largely elitist, the models in the commercial were overwhelmingly light skinned. In voice over, male voices were presented as 'authoritative", female voices as informative and 'seductive'.

- Women featured in all categories of commercials, but they were dominant in advertisements for food, grooming and household items.

- Less than three percent of telecasting time is devoted to programs on or for women, yet over 30 percent of advertising was directed to women, in the form of advertisement on cosmetics, beverages, fabrics and food products.

- The songs selected for telecast on PTV were by and large on religious themes or depicting themes of young women waiting to be married. The plays convey the message of the ideal women who is housewife and mother. If she is employed, then surely she must be reflecting her children or home. Stereotypes of women are reinforced in songs, commercial Jingles and plays.

- It is generally observed that the films emphasised young, beautiful and sexually attractive women; portrayed women in terms of their relationship to men; depicted women in traditional female occupation; and as overwhelmingly emotional superstitious dependent and irralational human beings. In most of the films character stressed marriages ass a goal for women and offered a double standard of morality (Shamsuddin, 2014).

- In another study John Lant revealed that that women continue to be portrayed in traditional ways and that in few films, women beating were popularised as a form of faming and romancing (Lent, 1985).

Documentaries on family planning contained a strong sexist bias as it. Underscored the importance of sons over daughters, the responsibility of family planning as a women's duty and the general passive nature of woman (Lent, 1985).

Studies of the newspapers have focused on the reporting of rape cases in the print media (as merely spicy news stories), the presentation of women in women's sections of daily newspapers, general interest magazines for instance, found that there were hardly any 
article devoted to serious discussion of women's problems at home at home or in the country.

The Washington Post published a story titled " In Pakistan five girls were killed for having fun. Then the story took an even darker twist; written by Pamela constable the story was a follow-up of a gave some case of five women from Kohistan whose lives, it is very strongly suspected, came untoward and cruel and for four years ago. All of them are said to have been killed on the orders of a Jirga, after a grainy video was shared, showing them clapping and singing at wedding ceremony. The fast finding mission told the Honourable Supreme Court of Pakistan that the women in fact, dead or missing on the assertations of the elders who maintained that they were alive were not true. This position was based in part on the fact that the experts in United Kingdom lacked at digital photographs of women presented and deemed they were not the same as the women in the video. Human Rights activists noted that there was very little like hood that women would have been spared. With video proof of their so called transgression and an edict reportedly demanding their killing, death was more or less inevitable (Zakaria, 2016).

Rafia Zakaria a women rights supporter, commenting the event wrote that the fact that elders in the village apparently thought they could simply produce another's set of girls, which seems to have been the case, and insist that no such thing had taken place is further evidence of what all Pakistan know i.e women's lives are worth little in Pakistan and women who dare to have fun, to be happy, are worth even less (Zakaria, 2016). Devoid of identity and individuality, the girls of Kohistan, like their sisters all around the country were considered interchangeable by the elders of their community, one exchanged for another, the dead for the living (Zakaria, 2016).

The Anti Honour crimes Bill was passed by the Pakistan National Assembly in October 2016, also faced controversy as opposition by the religious parties. However, the bill enhanced the maximum imprisonment for so called honour killers, who are most often close male relatives of the victims, regardless of whether or not they have been pardoned by their own family numbers. One hoped that the passage of the bill and the media attention around it would serve as a deterrent to would be honour murders to average their cruel conceptions of violation of their honour. However, if cannot be denied that in Pakistan violence in the name of honour is increasing in rural and tribal areas of the country.

It is surprising to note that honour killing is increasing in urban areas as well. In her book (Nafisa Shah) "Honour Unmarked: Gender Violence, Law, and Power in Pakistan", it was said "the statistics of women murdered in the name of honour know this grouse some act still prevails" (Rafi, H. (2016). The author wrote "The plots do no change, the character do .....the tradition of Karo Kari in Sindh has not changed and has been maintained" (Rafi, H. (2016). 
This is not only in the province of Sindh. In every province of Pakistan, brothers are killing their sisters and elite are just watching this unfold. The issue of women's rights is very pertinent issue and needs serious attention by the media. Pakistan Television and Radio Pakistan which could legitimately be used as public service information providers.

Media Houses pointing out to the inefficacy of teaching ethics in whatever form these are taught to media professionals. For instance the incident of a guard at a Nadra Office slapping a needlessly aggressive female reporter has divided opinion, on the one hand, there were those who have strongly criticised the assault on her person; on the other hand, several voices have approved of the guard's reaction. This has exposed an embedded acceptance of violence against women as means of restraining and controlling their behaviour. One writer stressed:-

"Certainly, a microphone wielding journalist crossing the limits in personal interaction deserves censura, but at the same time, the guard's violent response to the women's high handedness should not be lauded as befitting reaction, despite the rule books and manuals that caution against touching uniform; society must still secure all fronts to prevent such a scene from recurring"' (Aziz, 2016).

These which incident started the ethical dimension of professionalism of the journalists. Any discussion on ethics must refocus one's attention on the basic human value of respect and kindness. Incredibly, these simple values seems missing from the discourse on women in professional fields.

The Mac Bride Commission Report (1980) argues that media man has the following responsibilities:-

- Contractual responsibility in relation to her/ his media and his/ her internal organization.

- A social responsibility entailing obligation towards public opinion and society as a whole.

- "Responsibility towards the international community relating to respect of human values" (Many Voices, (1980).

The first responsibility of the media man is to observe ethics and the need to integrate practical implementation of ethical principles into professional training. The ethical consideration must be based on principles and values that uphold everyone's dignity. Any code of ethics will fail to achieve positive results if it is not been based on the basic of human values of fairness, kindness and respect to women, a prominent section of society.

The commission felt that codes of ethics at national and in some cases, at the regional level are desirable, provided that such codes are prepared and adopted by the profession itself without governments, interference. 
"Studies should be undertaken to identify, if possible principles generally recognized by the profession of journalists and which take account the public interest. This could also encompass further consideration, by Journalists, organization themselves, of the concept international code of ethics. Some fundamental elements for the code might be joined in the UNESCO Declaration on the mass media, as well as improvising common to the majority of existing national and regional codes', (Many Voices, 1980)

Media codes should take into account the following concepts:- (Merrill, 1989).

- Freedom of access to information sources.

- Safeguarding freedom of information.

- Objectivity, accuracy, truthfulness or the non misrepresentation of facts.

- Responsibility, to the public, and its right and interests and in relation to national, racia and religious communities, the nation, the state and maintenance of peace.

- The obligation to refrain from calumny, unfounded accusations. Lander, violations of privacy.

- Integrity and independence.

- The right of reply and of correction.

- Respect of professional confidentiality.

- Consideration for the cultural, social or ethnic codes of indivical countries.

The final formulation of the International Principles of "Professional Ethics in Journalism" was done by a working group composed of representatives of the International organization of journalists. The scope of professional ethics in much wider than the texts of legal codes. For, in attempting to achieve just balance between freedom and responsibility, the ethical aspects of his dichotomy depend not only on conscious decisions by a journalist, but also on practices in the media and the general social environment. It is recommended that codes of Ethics aim at the following objectives:- (Jacobson Thomas L. (1989).

- To protect the consumer readers, listeners viewer or the public in general.

- To protect and inspire the working journalist broadcaster or other who are directly concerned with the gathering writing, processing and presenting of news and opinions.

- To define the responsibilities of proprietors, shareholders and governments who are in a position of absolute control over any particular form of mass media communication activity.

- To deal with issues of advertisers and others who by the services of media.

The media, quite often discarded these values in favour of profiting aimed intense competition Asfiya Aziz wrote. 
"The ethical responsibility of society and to institutions in dealing with aggressive reporter is founded on the same values. However, a vital dimension is the difference in gender based perceptions of respect, we would do well as a society to acknowledge and find a way around these difference to be able to call ourselves a decent society, especially in an era of increasing female participation in the workforce' (Aziz, 2016).

A report by the Human Rights Commission of Pakistan reveals that in the last three years (Agha, 2017). (2014-16) about 2300 women have been killed in Pakistan in the name of "honour" despite all the legislation, honour killing are rising. Ms. Nadia Agha criticised:-

"Pakistani Women carry heavy burden of cultural norms, social practices and restricted opportunities, violence is often used as a tool to control and make them conform patriarchal ideology. This makes Pakistan one of the worst countries in the world for man" (Agha, 2017).

She quoted:-

According to Global Gender Gap Report, 2016, Pakistan rank 143 out of 144 countries on the gender inequality index, even below war torn countries like Syria (Agha, 2017).

The women in Pakistan step out of their sanctuary more than ticking clock on their mind. They are carrying the loud of their physical vulnerability, decades of negative endorsements from society concerns for their own safety and security, and awareness of the awareness of the consequences of mistake or accident.

The issue of honour killing is not a recent phenomenon. It is very much a part of life in the Indo-Pak. Sub Continent during the British Raj, under which Honur Killing were accommodated. The leniency of the British Raj towards this honour crimes resulted in strengthening this custom and transforming it into a legal defence (Agha, 2017). This legal defence became a useful tool in the pursuit of self interest, the majority of codes seam to emerge from fake claims with no witness or evidences. In a number of cases human are killed for exercising their right to marry a person of their choice. Such an act could lead to more women doing the same, which is perceived as a threat to male authority as the disintegration of existing power structures within families and communities could overrule their power. Nadia Agha also explaining the reasons of Honur Killing said:

"Unfortunately most of the legislative reforms to criminal violence against women in Pakistan meet with huge criticism and backlash adding further to the plight of women. Given to the current landscape, criminalising these acts and improving legislation for women's 
protection cannot address the issue adequately unless such laws are strictly implemented', (Agha, 2017).

Thus, to save women from Honour Killing, the Government should strictly feel its responsibility to implement the laws for women's protection. The zealous prosecution with good laws can make a great deal of difference.

Journalists must pay due attention to this issue and shall reveal the facts reporting to women and report and edit with fairness. Their responsibilities to the public are paramount. They are accountable to the public for their reports the women should be encouraged to vice their grievance against the media. Benjamin C. Bradlas, Executive Editor, Washington Post said that

"Editors are pledged to approach every assignment with fairness of open minds and without prior judgement. The search for opposing views must be routine. Government from persons accused or challenged in stories must be included. The motives of those who press their views upon us must be examined in routine, and if must be recognized that these motives can be noble and obvious and ulterior'' (Fedler, 1978).

The profession role of media is to pursue, not only truth in general, but the universal values of Romanism by transmitting facts and opinions independently. In February 1982? Helsinki put new universal doctrine by supporting "Pence Movement" in the union of Journalist in Finland for the attention of Western industrials power wrote:-

"The Journalist's instruction is the word. This instruction can be used only in conditions of peace; therefore promotion of pence is the most effective ways of depending freedom of speech. Every journalist can through his or her own work strengthen the structure of peace in society, in influencing public opinion and decision making. It is the duty of journalist to transmit truthful information about questions of pence truthful information about questions of peace and war, armament and national defence"' (Nordrenstreng, \& Hannikainen, 1984).

Journalists have an essential role in maintaining peace, by giving equal emphasis on women rights, because they accept crucial position, but it is to remember why they enjoy this position. As Tom Welsh and Walter Gunwood mentioned in the essential laws for journalists.

Journalists are pledged to avoid conflict interest (both for women and men, whenever and wherever possible. They enjoy a number of privileges and teach ties which citizen do not enjoy, extended to them by society or organizations in order to make it easier for them to 
do their job. It these facilities are withdrawn, possibly they may react in different manners, but these privileges are not rights and unless their withdrawal infringes the laws they have no legal redness.

Studies of the print media have focused on the reporting of rape cases in the press (as merely spicy news stories), the presentation of women in women's section of newspapers, general interest magazines and women magazines. The study mentioned earlier in this article (Shamsuddin M; Uses and Effects of Mass Media, 2014) wear of women sections in daily press, for instance, found that there were hardly any article devoted to serious discussion of women's problems at home or in society. When women are murdered, the government and public of large tend to make sense of violence. With each murder, new parameters are defined and the space for women shrikes. Much worse cold blooded its recast was a punitive act, making it acceptable when if should, instead, be deemed for more offensive to human decency and society values than anything the women could have done in the first place.

Huma Yosuf, a freelance journalists mentioned in the daily Dawn that when the Rock Band Bumber source wrote an anthem to Qandeel Baloch, Its members probably did not think it would soon be a lament. In an interview with BBC, Band frontman Masterjee Bumbu explained Qandeel Baloch Phenomenon, saying that she was a "Badly behaved women" who uses the internet to communicate, "those are two things Pakistan does not deal well with as a society; the internet and badly behaved women". His words were prescient Pakistan's inability to deal with Qandeel baloch's behaviour drove allegedly, her brothers to murder her in second week of July 2016 (Yusuf, 2016).

Qandeel Baloch's murder has been termed as "honour killing". Qandeel murder is the latest reminder that Pakistani society is an era of selective feminism.

Huma Commented:

"When if is convenient, people are happy to promote women's right; female entrepreneurship, which contributes to economy; girl's education which keeps international aid money flowing to state coffers, the election of female parliamentarians, who too party line and help boost Pakistan in gender equality indexes"' (Yusuf, 2016).

However, there is as little progress on issue that pertain to the security and sanctify of women themselves, from domestic violence to reproductive rights. Decades have passed, but the question of the gender in a balance in the society continuing which needs immediate attention of the government. Media should give more space to debate an the rights of women in our society. It has not been possible to make women friendly laws due 
to orthodoxy oppositions. Young women who would try to exercise their basic rights (even to marry of their choice) will go to waste if the media should not pay due attention to the issue seriously.

In an analysis quoted in John Lent, in three women magazines and two general interest magazines concluded that the fiction stories contained images and norms which should discourage female employment, particularly in higher status occupation (Lent, 1985). Women magazines have come in for a lot of criticism. Often they are no more than a mixed bag of recipes, tips on beauty aids, romantic stories, features and women's issues, women oriented advertisements and discussion on gender problem (Lent, 1985). Advertisements, even in women magazines were sexist. The content analysis revealed how women and children advertisers and manufacturers play on the susceptibility and vulnerability of women consumers and cheat them into buying food products, sanitary napkins, cosmetic, soaps etc are positively harmful to the health of their family. The study showed that man in advertisements are fully clothed, appear confident and dignified, while the women are presented a glamorous but in tradition roles (Lent, 1985).

In Pakistani society it is very common that women paid with their lives for arguing with their husbands and helped by their relatives to burn them alive. For example a women in Lahore (June 2016) (Lent, 1985). arguing strangulated her daughter for taking a spouse of her choice and than set on fire. In another incident in a village, a man shot dead his daughter for having exercised her rights to marry of her face will along with her husband (Khan, 2016). These kinds of incidents are growing day by day and reported by newspapers, which shows intolerance for women's right not only among men but also among women themselves. Mass Media should play a role in educating women rights in the society.

\section{Conclusions}

Rational debates must be reviewed by the media emphasis on human rights including women rights is not only a western idea but also an Islamic ideal. In fact Islam improved it. Act of burying girls alive were banned. Racial bias was discouraged. Slavery was curbed. Islam improved human rights. Emphasis on education should be given. Islam supports democracy, education and rights for woman. Extremism is a bigger problem of our society. Ignorance breeds ignorance. Our young men and women have no real institutions for guidance on the equal rights in the society. Women have a right to equality, and more fundamentally, the right to life. If we cannot ensure this in the 21 century, we will remain locked in medieval ages and can only dream of a society, we can take pride in. The powerful character of media in depth, on the socials, moral, political, economical, religious and other factors will contribute to the benefit of masses in making the awareness of human rights, duties privileges and above all, women affection and religions proximity in our society. Media functions as supportive and reinforcement tool 
in transmitting positive attitudes and influencing a behavioural change to the maximum level, the mode of persuasion for educating people. Media not only inform but also serve the cultural purpose of minimizing the tensions among nations and simultaneously lead to enhance peace and harmony. The positive cultural values can easily be made clear through media.

Attempts must be made to restyle the traditional women's pages both in content and positioning in newspapers, to give more space to gender issues an opportunity to write about more on important issues the right of women in society, and the placement of news about women issues on media. Either because of ignorance on how to deal with gender issues or because of the women in important positions in newspapers decision making jobs, journalism in Pakistan can correctly be criticised for continued under representation of women in hard news of print media and news bulletins of the radio and television. Apart from underrepresentation of women in news presentation in our society, there has been a problem of attitude to women in the media, which is prevalent in certain stereotyped images in which women are either 'good' and 'bad' or 'pure' and immoral. The good women are those who are confined in homes and taking care of their families and are dependent on men. The inferior status of women in social, cultural and economic walks of life is shown as accepted norms in both fictional character and actual newsmakers. The stories covered in media shows men with strength, leadership, decision making and independence and women with very opposite of these characteristics. Hence Journalists in our society wrote hardly any stories about violence against women, give space on inside pages as fillers. Every day women are being seriously injured or killed by their husbands who are only disciplining then by physically beating them without covering print media about these shameful activities. The journalists should give equality by not discriminating against anyone on the basis of his or her race, ethnicity or religion, social class, profession, handicap any personal characteristics or gender discrimination.

\section{References}

Agha, Nadia (2017). “In Honour's Name”, January 4, Daily Dawn, Karachi.

Aziz, Asfiya (2016). “Spectre of Contempt”, October 31, Daily Dawn, Karachi.

Bromley, Michael (1994). Teach Your Felt Journalism, UK: Hodder and Strughton, p.6.

Fedler, Fred (1978). Reporting for the Print Media, Washington: Hasrcourt Brace Jovanorich, p.2.

Jacobson Thomas L. (1989). Discourse Ethics and the Right to Communicate, International Communication Gazette, vol.60:5, pp.395-413. 
Khan, A.A (2016). The Missing Daughters of Pakistan, Herald, September, 11, 2016

Kunczik Michael (1999). (Ed.); Ethics in Journalism, Germany: Friedrich Ebert Stiftung, p.13.

Lent, John (1985). Women and Mass Communication: The Islam Literature, Gazette, vol.35, pp.124-142.

Merrill, John C. (1989). Global Communities for Journalistic Ethics; USA, (a summary from the book)

Nordrenstreng, K \& Hannikainen L; (1984). The Mass Media Declaration of UNESCO; Norword, W.J. Abled Publishing Corporation, p.318.

Rafi, H. (2016). "Honour Killings increasing in Urban Areas", December 22, Daily Dawn, Karachi.

Robertson, Geoffery (1995). Media Law; London; Sage Publication, p.338.

Sani, Hafiz Muhammad, (1999). Mohsin-e-Insaniat our Insani Haqooq, Karachi: Darul Ishraat, p.137

Seen, MacBride, (1980). Many Voices one World, Paris: UNESCO, pp.242-244.

Shamsuddin, Muhammad (2014). Uses and Effects of the Mass Media, Department of Mass Communication, University of Karachi (Unpublished Survey)

Shamsuddin, Muhammad (April 2014). Ethical Perspective on Mass Communication; The Journal of Mass Communication, University of Karachi, vol.2:1, pp. 8-9.

Yusuf, Huma (2016). “The Real Islam”, July 18, Daily Dawn, Karachi.

Zakaria, Rafia, (2016). “Women having Fun”, December 21, Daily Dawn, Karachi.

Dr. Abida Perveen is an Associate Professor and Acting Director in the Sheikh Zayed Islamic Center, University of Karachi.

Dr. Muhammad Shazad is an Assistant Professor in the Department of Media Studies, Islamia University, Bahawalpur. 